\title{
PREVALENCE OF PARASITIC HONEYBEE DISEASES, PESTS AND PREDATORS IN NORTH GONDAR ZONE
}

\author{
Tadele NEGA, Muluken YAYEH, Tadegenge MITIKU, Mastewal BIRHAN ${ }^{\star}$, Basazenew BOGALE, Meresha \\ CHANIE and Amebaye KINUBEH \\ College of Veterinary Medicine and Animal science, Department veterinary Paraclinical studies, University of Gondar, Gondar, Ethiopia \\ 凹E-mail: Maste675@gmail.com; ORCID: 0000-0002-0984-5582
}

\begin{abstract}
A cross-sectional study was conducted on parasitic honeybee diseases, pests and predators Lay armachiho and Tach armachiho districts of North Gondar zone from October 2017 to May 2018. The objectives of this study were to assess the different parasitic honeybee diseases, pests and predators. The study mainly involves with the collection of adult honeybee abdominal suspension of wet mount for nosema and amoeba diseases and direct observation of varroa mite and bee louse from adult honey bee and brood cells. Questioner survey was used to know different honeybee pests, predators and agrochemicals in the study area. The SPSS version 20 was used for chi-square test and $p$-value $<0.05$ was taken as statistical significant. During the study period a total of 384 honey bee sample in traditional, modern and transitional hives were examined. The overall prevalence $24.47 \%(94 / 384)$ of hives were found positive for Nosema apis, $17.2 \%(66 / 384)$ foramoeba (malphighamoeba mellificae), $30.5 \%$ (117/384) for varroa destructor and 37.5\% (144/384) for bee louse (braula cocae). Bee louse was the predominant external parasitic disease in adult honeybees followed by varroa destructor. There was statistically significant variation between Nosema Apis and bee louse observed among the two selected districts and hive types $\left(x^{2}=23.5\right.$, $p$-value $\left.=0.0001\right)$ for bee louse and $\left(x^{2}=5.3, p\right.$-value $\left.=0.071\right)$ for Nosema Apis. About the 100 respondents are 46\%, 42\%, 39\%, 35\%, 28\%, small hive beetle 26\% and spider $\mathbf{2 4 \%}$ were complaining on the impact of wax moth, chemical spray, skunk, birds, small hive beetle and spiders respectively. They have also responded that pests play a major role on the production loss, damaging of honey bee colony and absconding of the colony. In conclusion, the highest prevalence parasitic honeybee diseases and pests were recorded in the study areas that signify the occurrence of the parasitic burden has to be carried out and immediate intervention was implemented.
\end{abstract}

Keywords: Honeybees, Parasites, Pests, Traditional And Modern

\section{INTRODUCTION}

The essential and valuable contributions of honeybees depend upon the healthy population of honeybees (FAO, 2012). The health of honeybees has been one of the most important topics in apiculture research in recent years (Genersch, 2010). This is mainly associated with the recent emergence of high honeybee colony losses in many parts of the world and the vulnerability of honeybees to parasitic mites, fungi, viruses and bacteria (Bradbear, 2009). These pathogens and parasites can have harmful effects on honeybee health and the services they offer, which in turn can lead to severe economic losses (Genersch, 2010).

Moreover, modern agriculture increasingly depends on the use of chemical substances to control weeds, fungi and arthropod pests to ensure high yields. Honey bees may frequently become exposed to environmental chemicals as a consequence of their foraging activities (Vanengelsdorp and Meixner, 2010). It has been reported that several biological and environmental factors acting alone or in combination have the potential to cause premature colony mortality. In United States the average honeybee loss per beekeeping operation was $25.4 \%$ (Spleen et al., 2013). Similarly, $16 \%$ honeybee colony reduction has been reported in Europe (Hendrikx et al. 2010; Potts et al., 2010).

The ectoparasitic mite Varroa destructor as well as the bee pathogenic viruses have been identified as a marker of dramatic colony losses termed colony collapse disorder in the USA, the Microsporidium nosema species and bacterial diseases are causing economic losses to beekeepers worldwide (Genersch, 2008). Even though, the majority of pathogens and parasites affecting honeybees have an almost worldwide distribution (Ellis and Munn, 2005).

The most commonly known honeybee diseases reported to exist in Ethiopia are Nosema Apis and Melpighamoeba mellificae (Amssalu Bezabeh and Desalegn Begna, 2005).To this effect, honeybee diseases are report to be among the major constraints in beekeeping (Workneh Abebe and Puskur, 2011). The identification and severity of each economically important honeybee disease have not been well documented in amhara region, despite little information is available. To fully exploit the opportunities in beekeeping sector, addressing the constraint and detecting the occurrence and distributions of honeybee's health problems is key step to prevent their harmful effects. Therefore, the objectives of this study were: A) to determine the occurrence and prevalence of parasitic honeybee diseases and pests; B) To determine the 
effect of honeybee disease on honey bee colonies and their products; C) To assess the different risk factors associated with honeybee parasitic disease, pest and predators of the honeybees.

\section{MATERIALS AND METHODS}

\section{Description of Study area}

The study was conducted in the selected district of north Gondar zone, north east of Ethiopia, (lay armachiho and tach armachiho) from October 2017 to May 2018. These areas are located 763, $810 \mathrm{kms}$ from Addis Ababa respectively. The climatic condition of the study areas are highland and kola and its annual temperature range from $10^{\circ} \mathrm{c}-40^{\circ} \mathrm{C}$

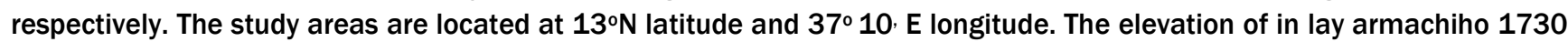
and tach armachiho 950-1100 m.a.s.l and its annual rain fall in tach armachiho and lay armachiho is $300-750 \mathrm{~mm}$ with slight rain in April and May and heavy rain in July and august.

\section{Study design}

A cross-sectional study was conducted on honeybee colonies to assess the prevalence of common parasitic honeybee disease, pest and predator by using microscopic examination for protozoa parasite and macroscopic examination for Varroa mite and bee louse from adult worker honey bee. Semi structured questionnaire was administered from each apiarist to assess honeybee parasitic disease, pest and predator in the study area.

\section{Study population}

The study districts have traditional, modern and transitional types of hive in the north Gondar zone and most of bee hives are managed under traditional system. The study was conducted in all types of honeybee hives to estimate the prevalence of parasitic honeybee diseases, predators and pest. The honeybee colonies were selected randomly and collection of these adult bees were at the entrance of honeybee hives for Varroa mites. The colonies were randomly selected from the study areas 10-20 bees were taken from the top frames and hive entrances of each of these colonies and placed in separate transparent sample bottle. The collected bees were immediately immersed in to $10 \%$ formalin or $70 \%$ ethanol during sample transportation. Sample size determination and sampling method

The required sample size for this study was estimated by assuming expected prevalence of $50 \%$, and study on parasitic honey bee disease and pest in the study area. Thus the sample size collected according to Thrusfield (2005) using $95 \%$ confidence interval at $0.05 \%$ absolute precision and calculated by the following formula.

$$
\mathrm{n}=\frac{(\mathrm{Za})^{2} X \operatorname{Pexp} X(1-P \exp )}{\mathrm{d}^{2}}
$$

Where, $\mathrm{n}=$ required sample size, Pexp= Expected prevalence $(50 \%), \mathrm{d}=$ Desired absolute

Precision (5\%), Za=confidence level, 95\%=1.96

By using 50\% expected prevalence with $95 \%$ confidence interval at $5 \%$ absolute precision (Thrusfield, 2005). The number of hives required estimating the prevalence of honeybee disease and pest was calculated to be 384 . A total of 384 bee colonies were selected by randomly and collected honey bees from sampling sites. The sample was collected during at night time to reduce disturbance of bees in the environment. After wearing of protective cloth and beekeeper glove samples were collected from the selected hive in a jar by using bee brush and preserve $70 \%$ ethyl alcohol or $10 \%$ formalin and labeled immediately.

\section{Study methodology}

Microscopically examination for nosema and amoeba

For quick qualitative examination of nosema spores and amoeba cysts, the abdomen from at least 10 sample bees were remove, place in pistle and crush using mortar and pistle by adding distle water ( $1 \mathrm{ml} /$ abdomen) and homogenize. A wet mount was prepared from the resulting suspension and the existence or non-existence of nosema spore was examined by $100 x$ and used oil immersion for magnification of the field.

\section{Macroscopic examination procedure for varroa mite and bee louse}

Varroa mite is dislodging by shaking the sample bees in liquid such as water, $70 \%$ alcohol, detergent solution and $10 \%$ formalin. Hand shaking bees in alcohol for 1 minute dislodge about $90 \%$ of the mite. The mite was directly observed by the naked eye from the transparent sample bottle or beaker, the parasite settle at bottom of beaker and the sample adult bees were float above liquid.

In bee louse the sample were examined using shaking method, bees sample preserved were taken and detergent solution $(10 \mathrm{ml}$ of detergent is used to $1000 \mathrm{ml}$ of detergent-water solution) was poured into each of jar containing bees up to half of the jar get full. Then shaking for one minute until the lice dislodged from adult honeybees. Straining the solution through a ladle (8-12 mesh) to remove the bees and then sieving the solution through tea strainer to collect bee lice. The tea strainer was examined for presence of bee lice either by necked eye or by using hand lens and count bee lice (Cramp, 2008). 


\section{Questioner survey and regular visits}

The questioner was conducted to acquire information on observing clinical sign of honey bee disease, pest, management (feeding, watering, cleaning), types of hives, absconding, and related problem. These questioner surveys were collected from apiarists and extension workers of the districts using structured interview, observations and personal interviews.

\section{Data management and analysis}

All data was entered in to Ms- Excel spread sheets after the completion of data collection work from the study areas. Then, the analysis was done by using SPSS version 20 , while the result was summarized by using descriptive statistics (means, standard errors and percentages).

\section{RESULTS}

\section{Laboratory finding}

A total of 384 honey bee colonies were examined and $24.47 \%$ (94/384) were positive for Nosema APIs, $17.2 \%$ (66/384) for amoeba disease (Malphighamoeba mellificae), $30.5 \%$ (117/384) for varroa mite (varroa destructor or varroa jacobsoni) and $37.5 \%(144 / 384)$ for bee louse (braula coeca). Bee louse was the highest external parasitic disease in adult honey bees and followed by varroa mite in the current study. Both protozoan parasitic honey bee disease (Nosema APIs and Malphighamoeba mellificae) were found in the abdominal contents of the adult honey bee colonies. The prevalence of all bee hives examined for parasitic honey bee disease and pests contributed from two selected districts in north Gondar zone (tach armachiho and lay armachiho).

\section{Risk factors}

The assessment of the risk factors by using questionnaire and regular visits in two districts showed that hive type in the apiarists used and the study districts were the major predisposing factor. But these risk factors were not found affecting the prevalence of parasitic honey bee diseases statistically except bee louse.

\section{Districts}

During the study period the prevalence of nosema, amoeba, varroa mite and bee louse of parasitic honey bee disease in tach armachiho and lay armachiho were presented in (Table 1). The prevalence of Nosema apis in these two selected districts are $\mathbf{2 2 . 8 \%}$ and $\mathbf{2 6 . 1 \%}$ respectively, however there was no statistically significance difference $(P>0.05)$ between the study area.

\section{Hive type}

Among 201 traditional bee hives, 123 modern bee hive and 60 transitional bee hives examined $27.9 \%, 18.7 \%$ and $16.7 \%$ were positive for nosema apis respectively. Even though the higher prevalence of Nosema Apis was observed in traditional bee hives, it was not significantly difference $(P>0.05)$ (Figure 1 ).

Prevalence of Malpighamoeba mellificae was $15.2 \%$ and $19 \%$ in tach armachiho and lay armachiho respectively (Table 1). The prevalence of Malpighamoeba mellificae almost similar in two districts and there was no statistical significance difference $(P>0.05)$ between two districts. Of 201 traditional hives, 123 modern and 60 transitional hives examined $16.9 \%, 11.4 \%$ and $13.3 \%$ were positive for Malpighamoeba mellificae respectively as seen from (Figure 2). Even if higher prevalence of Malpighamoeba mellificae was observed in traditional bee hives the association between hive type and the occurrence of Malpighamoeba mellificae was not significance difference $(P>0.05)$. During the study period, the prevalence of varroa mite and bee louse in two districts was recorded in the result. The result revealed that the prevalence of bee louse was $35 \%$ and $40.2 \%$ respectively (Table 1). Relatively highest prevalence of bee louse was observed in tach armachiho than lay armachiho. However, the association between the districts and causative agent were statistical significance $(P<0.05)$. The prevalence of varroa destructor in these two districts was $28.8 \%$ and $32 \%$ respectively (Table 1). However, the association was not statistical significance $(P>0.05)$. Origin and hive type were the two most important risk factors for the occurrence of honey bee mite. From 201 traditional hive, 123 modern hives and 60 transitional hive examined $26.4 \%, 17.8 \%$ and $18.3 \%$ varroa destructor positive colonies and $37.3 \%, 32.5 \%$ and $33.3 \%$ bee louse positive colony were found respectively (Table 2) and the higher prevalence of bee louse and varroa mite was observed in traditional hive and the association result in the case of bee louse.

\section{Prevalence of honeybee pests, predators and pesticides}

Based on this, the existence of pests was the major challenge to the honeybees and beekeepers. After identifying the major pest facing the beekeeping activities, the prevalence of major bee enemies in two selected districts of north Gondar were listed according to farmer perception (Table 3). From the lists of pests and predators in the study area wax moth and honey badger were found significantly affecting the honey bee hives but the other pests and predators was not significant. 
Table 1 - Prevalence of Nosema APIs, M. Mellificae, varroa mite and bee louse in two districts of north Gondar

\begin{tabular}{|c|c|c|c|c|c|c|}
\hline \multirow{2}{*}{$\begin{array}{ll}\text { Honey bee parasite } & \text { Districts } \\
\end{array}$} & \multicolumn{2}{|c|}{ Tach armachiho } & \multicolumn{2}{|c|}{ Lay armachiho } & \multicolumn{2}{|c|}{ Total } \\
\hline & Negative & Positive & Negative & Positive & Negative & Positive \\
\hline Nosema a & $136(73.9 \%)$ & $42(22.8 \%)$ & 154(77\%) & $50(26 \%)$ & $290(75.5 \%)$ & $94(24.47 \%)$ \\
\hline Amoeba ${ }^{b}$ & $156(85 \%)$ & $28(15.2 \%)$ & $162(81 \%)$ & $38(19 \%)$ & $318(83 \%)$ & $66(17.2 \%)$ \\
\hline Varroa mite $^{c}$ & 131(71.2\%) & $53(28.8 \%)$ & $136(68 \%)$ & $64(32 \%)$ & $267(69.5 \%)$ & $117(30.5 \%)$ \\
\hline Bee louse $^{d}$ & $110(60 \%)$ & $74(40.2 \%)$ & $130(70.6 \%)$ & $70(35 \%)$ & $240(62.5 \%)$ & $144(37.5 \%)$ \\
\hline
\end{tabular}

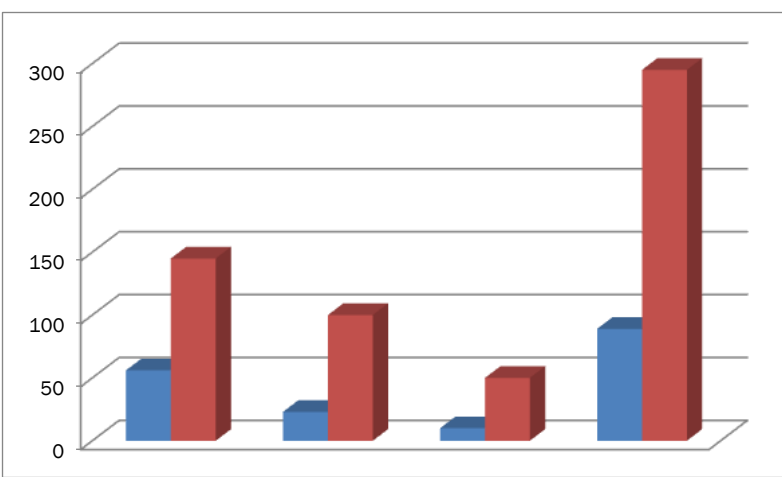

Figure 1 - Nosema Apis is showed more prevalent in traditional hives than modern; hive $\mathrm{X}^{2}=5.3$, df $=2$, and $\mathrm{p}$ value $=\mathbf{0 . 0 7 1}$

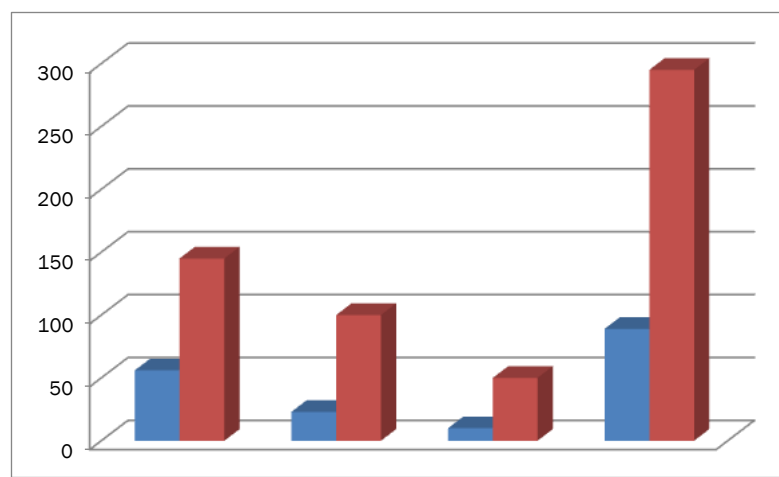

Figure 2 - Prevalence of amoeba in traditional hives is higher than modern hives; $X^{2}=1.96, d f=2$, and $p$ value $=0.374$

Table 2 - Prevalence of varroa mite (varroa destructor) and bee louse (braula coeca) in three types of honeybee hives from two selected districts of north Gondar zone.

\begin{tabular}{|c|c|c|c|c|c|}
\hline \multicolumn{2}{|c|}{$\begin{array}{ll}\text { Causative agent } & \text { Hive type } \\
\end{array}$} & Traditional & Modern & Transitional & Total \\
\hline \multirow{2}{*}{ Varroa destructor a } & Positive & $53(26.4 \%)$ & $22(17.8 \%)$ & $11(18.3 \%)$ & $96(25 \%)$ \\
\hline & Negative & $148(73.6 \%)$ & $101(82 \%)$ & $49(81.6 \%)$ & 355(92.4\%) \\
\hline \multirow{2}{*}{ Bee louse $b$} & Positive & 75(37.3\%) & $40(32.5 \%)$ & $20(33 \%)$ & 135(35.2\%) \\
\hline & Negative & $126(62.7 \%)$ & $83(67.5 \%)$ & 40(66.7\%) & 249(64.8\%) \\
\hline
\end{tabular}

Table 3 - Farmer perception on the Prevalence of honeybee pests, predators and use of chemicals

\begin{tabular}{|c|c|c|c|c|c|}
\hline Major pests and predators & $\begin{array}{l}\text { Total sample } \\
\qquad(n=100)\end{array}$ & Positive & Chi-square $\left(X^{2}\right)$ & df & p-value \\
\hline Wax moth & 100 & $46(46 \%)$ & 7.8 & 1 & 0.005 \\
\hline Spider & 100 & $24 \%$ & 0.16 & 1 & 0.68 \\
\hline Small beetles & 100 & $26 \%$ & 1.46 & 1 & 0.22 \\
\hline Ant & 100 & $28 \%$ & 0.12 & 1 & 0.81 \\
\hline Birds & 100 & $35 \%$ & 1.99 & 1 & 0.15 \\
\hline Lizard & 100 & $16 \%$ & 0.04 & 1 & 0.84 \\
\hline Chemical spray & 100 & $42 \%$ & 0.65 & 1 & 0.41 \\
\hline Honey badger & 100 & $19 \%$ & 5.26 & 1 & 0.02 \\
\hline Qunchichr & 100 & $23 \%$ & 0.17 & 1 & 0.68 \\
\hline Skunk & 100 & $39 \%$ & 0.04 & 1 & 0.82 \\
\hline
\end{tabular}

\section{DISCUSSIONS}

The prevalence of nosema apis reported in the present study was relatively lower than previous reports in Ethiopia was reported from different regions with varying prevalence ranges such as $58 \%$ in Oromia, $60 \%$ Benishangul-Gumuz and $47 \%$ in Amhara regions by Aster Yohannes et al. (2010) and other countries such as Nigeria (64.29\%) by Akinwande et al. (2013), Kenya $83.3 \%$ by Fazier et al. (2010) and Turkey $65.25 \%$ by Aydin et al. (2001) and Diagnosis made on honey bees 
in field and laboratory at Addis Ababa reported a prevalence rate of $73 \%$ of amoeba prevalence. The diseases was also reported with high prevalence rate in different regional state of Ethiopia such as; Oromia region with prevalence rate (88\%), Amhara region (95\%) and $60 \%$ in Benishangul- Gumuz by Aster Yohannes et al. (2010).

The prevalence of parasitic honey bee disease in the selected districts is relatively higher in traditional bee hive than modern and transitional hive type. The result of this study indicated that either origin or hive type not significance influence in prevalence of parasitic honey bee disease in the study area except bee louse which was strong statistical significance in the origin ( $P=0.00$ ) with $35.5 \%$ prevalence. The difference prevalence of the study area of the disease may be colony management of the beekeepers during swarming, extraction of honey and stress condition. Tach armachiho districts have relatively less prevalence in Nosema Apis (23\%) and $28.8 \%$ of varroa destructor as compared to lay armachiho districts, which have high prevalence. This is due to dry climatic condition which crates less favorable condition. In lay armachiho districts the honeybee beekeepers were contamination of colonies with honey extracting equipment was observed that aggravates the spread of protozoan parasitic disease. In addition to this less awareness about beekeepers for honey bee colony and less practice of modern hive type was the cause of increasing parasitic infection rate in the study area. The observed overall prevalence of Varroa mite and bee louse in the study area was lower than in the reported in some African countries such as Tanzania and Uganda $84.6 \%$ by Fazier et al. (2010), Nigeria 78.6\% by Akinwande et al. (2013), and 100\% in Jordan by Alattal et al. (2006) and the overall prevalence of bee lice observed in the current study was much greater than the previous reports in Wukro woreda 5.5\% by Adedy Gidey et al. (2012), the current finding was also much lower than the report in and around holeta $42 \%$ by Gizachew et al. (2013), Jordan $64.3 \%$ by Al-Ghzawi et al. (2009), South Africa $92 \%$ by Strauss, et al. (2013). The variation of the prevalence due to ecological and climatic difference, types of hive and improper hive management, seasonal difference and the high density of honey bee colonies in one apiary are the major challenges of honey bee. In Ethiopia, as one of the subtropical countries the land is suitable to honeybee and different types of pest and predators that are interacting with the honeybee (Keralem et al. 2009). Based on the respondents complain the wax moth, honey badger, birds ant, spider, small hive beetles and others has higher prevalence rates (16-46\%) and they were the most harmful pests and predators. They are also decreasing honey production, causes of swarming, causes of absconding and damaging of different types of hive. Some pests simply use the hive for living and shelter their own nest but some pests caused harmful by feeding on pollen, honey and beeswax (Tessega, 2009) in Burie district north west Ethiopia.

According to the survey, most honey bee hives were damaged by pests and parasitic disease but the severity of pests and parasitic disease varied from hive to hive and apiary to apiary. The traditional hive where found heavily attacked by pests because of the materials and difficult to control the pests and predators due to limited accessibility to the hives, different types of size and shapes. The modern hives were less damaged by pests and parasitic honeybee disease due to the beekeeper can easily inspect the hives and control the pests (Kajobe et al., 2009) reported from Uganda. The occurrence of honey bee pests were $46 \%$ for wax moth, $28 \%$ for ant, $35 \%$ for birds, $19 \%$ for honey badger and $26 \%$ for small hive beetles. From the total respondents $42 \%$ had observed agrochemical poisoning and attack their colonies using herbicide for cereals and crops. This reported by Tessega (2009) that performed many beekeepers lost their honey bee by every year because the farmer used agrochemicals for crop and cereals.

Most honeybee keepers used traditional protection method to control different types of honeybee pest and predators in the study area such as clean the hive, removal of the old comb, place fresh ash, hot water for ants and application of dirty engine oil. These control method for honeybee pests and predators were practice in different regions of Ethiopia reported by Gidey et al. (2011) in northern parts of Ethiopia.

\section{CONCLUSION AND RECOMMENDATIONS}

Alarmingly increasing honeybee colony losses have been reported from researches over the last few years. From recent survey of honeybee losses in Ethiopia it became evident that pests and parasitic diseases could be identified as the most important cause of these colony losses. Several colony losses honeybee diseases which are thought to be involved in such honey bee colony losses. Therefore, in Ethiopia diverse pathogens are involved in the presumed inexplicable colony losses. Although the decline in managed honeybee equally seems to be problems in North Gondar despite great differences in beekeeping practices, the factors responsible for colony losses differ from region to region and from site to site. It should be prepared that it does not find a globally valid solution to honeybee decline but that will have a panel of possible factors, all of them asking for a specific solution to address the problem. If we are to explain unusual colony losses and if we are to find the cause for these losses, then we need to move from the mere detection of bee parasitic diseases in individuals and colonies to molecular bee disease focusing on host and vector interaction of parasitic disease with equal emphasis on the disease or vector and host. To understand the parasitic disease of honeybees this in turn will enable us to develop adequate control measures. In order to reduce a disease to the best advantage, it is clear that its cause must be known as well as the means by which the infection is transmitted and the environmental condition which are favorable for the breaking out of the disease.

Based on the above conclusion the following recommendation forwarded:

$>$ Further study should be under taken on parasitic honeybee disease with more diagnostic tests to generate more reliable data. 
$>$ The study survey should be carried out during different season of the year to know adequate data on the distribution of different parasitic honeybee disease in different seasons.

$>$ Special attention should be given for bee louse and varroa mite infestation in honeybee

$>$ Any apiarists and farmers should be intensively encountered to change the traditional bee hive into modern type and give advice to manage properly by cleaning their apiary and bee hives.

$>$ Government, researchers and beekeepers should be focused on the effects of agrochemical application on honeybees and to minimize their effects as well as on the development of non-chemical methods of herbicide, insecticides and pesticides control measures.

\section{DECLARATION}

\section{Corresponding author}

Dr. Mastewal Birhan (MB) = maste675@gmail.com; ORCID: 0000-0002-0984-5582; Co-authors: Mr. Tadele Nega $(T D)=$ tadelenega21@gmail.com; Dr. Muluken Yayeh $(M Y)=$ yayehmulu@gmail.com; Dr. Mastewal Birhan $(M B)=$ maste675@gmail.com; Dr. Tadegenge Mitiku $(T M)=$ tadevet2012@gmail.com; Dr. Basazenew Bogale (BB)= basaznew2008@yahoo.com; Prof. Meresha Chanie (MC)= kasuamare@gmail.com; Dr. Amebaye Kinubeh (AK)= ambayken@yahoo.com

\section{Authors' contributions}

MB conceived the study, coordinated the overall activity, and carried out the statistical analysis, drafted the manuscript. TD, AK, TM, BB participated in drafting and reviewing the manuscript. MY conceived the study, coordinated the overall activity, and reviewed the manuscript. MC participated in drafting and reviewing the manuscript. TN participated in the design of the study, and reviewed the manuscript. All authors read and approved the final manuscript.

\section{Acknowledgment}

The authors' heartfelt thanks will also go to University of Gondar, V/P of Research and community service office and CVMAS for the financially supporting.

\section{Availability of data and materials}

Data will be made available up on request of the primary author

\section{Consent to publish \\ Not applicable.}

\section{Competing interests}

The authors declare that they have no competing interests.

\section{Funding}

This study was funded by the University of Gondar. The views presented in the article are of the authors and do not necessarily express the views of the funding organization. The University of Gondar was not involved in the design of the study, data collection, analysis, and interpretation.

\section{REFERENCES}

Adedy G, Shiferaw M and Abebe (2012): Prevalence of Bee Lice Braula coeca (Diptera: Braulidae) and Other Perceived Constraints to Honey Bee Production in Wukro Woreda, Tigray Region, Ethiopia. Global Veterinarian, 8 (6): Pp 631635.

Akinwande L, Badejo A and Ogbogu S (2013): Challenges associated with the honey bee (Apis mellifera adansonii) colonies establishment in south western Nigeria. African

Akinwande L, Badejo A and Ogbogu S (2012): Incidence of the Korea haplotype of Varroa destructor in southwest Nigeria. Journal of Apicultural Research, 15: Pp 369- 370.

Alattal R, Claus P and Zebitz (2006): Infestation levels of Varroa destructor in local honey bees of Jordan.15: Pp 321-326

Al-Ghzawi A, Zaitoun T and Shannag K (2009): Incidence and Geographical Distribution of Honeybee (Apis mellifera) Pests in Jordan. Ann. soc. entomol. Fr., 45 (3): Pp 305-308.

Amsalu B and Desalegn B (2005): Distribution of honeybee diseases Nosema APIs and Melpighamoeba mellificae in Ethiopia. $4^{\text {th }}$ Proceedings of Ethiopian Beekeepers Association, Addis Ababa, Ethiopia, Pp 19-26

Amsalu B and Desalegn B (2001): "Survey of honeybee pest and Pathogen in South and Southwest parts of Ethiopia". Pp. 86-93,

Amsalu B, Alemayeh G, Gemechis L and Kibebew W (2010): "Diagnostic survey of honeybee diseases and pests in Ethiopia.

Amssalu B and Desalegn B (2006): Occurrence of small hive beetle (Aethina tumida) in honeybee (Apis mellifera) Ethiopian Veterinary Journal. 10: Pp. 101-110.

Amssalu B and Desalegn B (2008): Study on the ecological distribution of small hive beetles in maize-coffee growing areas. 
Amssalu B (2012): Prevalence and Effects of Nosemosis on Central highland honeybees (Apis mellifera bandasii).

Aster Y, Amssalu B, Betre Y, Desalegn B, Yosef S, Yosef K and Nohe K (2010): Ecological distribution of honeybee Chalk brood disease (Ascosphaera Apis) in Ethiopia. Ethiopian Journal of Animal Production 9(1): Pp 177-191

Aydin L, Gulegen E, Cakmaki I, Girisgin G, and Harrington W (2006): Relation between Nosema and Chalk brood disease and its implication for an apiary management model. Bull Vet Inst Pulawy, 50: 471-475

Bradbear J (2009): Bees and their roles in forest livelihoods: A guide to the services provided by bees and the sustainable harvesting, processing and marketing of their products. FAO Non-Wood Forest Products 19, FAO, Rome.

Coffey M (2007): Parasites of the honeybee. The Department of Agriculture, Fisheries and Food, Crops Research Centre, Oak Park, Carlow, Ireland

Conte Yand Navajos M (2008): Climate change: impact on honey bee populations and diseases. Rev. sci. tech. Off. int. Epiz., 27 (2): Pp 499-510.

Cramp D (2008): A practical manual of bee keeping. United Kingdom. Oxford. Available at http://files.uniteddiversity.com/beekeeping/A practical manual of beekeeping.pdf

Desalegn B (2014): Occurrences and distributions of varroa mite (Varroa destructor) in Tigray regional state, Ethiopia Journal of Fisheries and Livestock production, 2(3):1-4.

Desalegn B. (2007): Assessment of the effect of ant (Dorylus fulvus) on honeybee colony (A. mellifera) and their products in West \& South-West Shoa Zones, Ethiopia. Ethiopian Journal of Animal Production; 7(1): Pp 12-26.

Ellis D (2004): The ecology and control of small hive beetles (Aethina tumida Murray) Rhodes University, Graham's town, South Africa, $385 \mathrm{pp}$.

Ellis D (2008): Bee louse, bee fly, Braulid, Braula coeca Nitzsch (Diptera: Braulidae). In J L Capinera, Encyclopaedia of Entomology. Springer; Berlin, Germany, Pp 417-419

Ellis D and Munn A (2005): The worldwide health status of honey bees. Bee World, 86: Pp 88-101.

Ellis D, Graham R, and Mortensen A (2013): Standard methods for Wax moth research. In: V Dietemann; J D Ellis; P Neumann (Eds).The COLOSS BEE BOOK.Volume II: standard methods for Apis mellifera pest and pathogen Research: Journal of Apicultural Research, 52(1). Pp 1-17.

Ellis D.and Macedo A (2001): Using the Sugar Roll Technique to Detect Varroa Mites in Honey Bee Colonies. Lincoln, NE: University of Nebraska. $4 \mathrm{Pp}$

Etsay K and Ayalew K (2001): "Survey on honeybee diseases and pests in Tigray". Bureau of Agriculture and National Resources (BOANR), Mekelle, Ethiopia.

Fakhimzadeh K (2001): Detection of major mite pests of Apis mellifera and development of non-chemical control of Varroasis. Department of Applied Biology, $46 \mathrm{Pp}$

FAO (2006): Honey bee diseases and pests: A practical guide. Food and Agriculture Organization of the United Nations (FAO agricultural and food engineering technical report 4), Rome, Italy, $33 \mathrm{pp}$.

FAO (2012): Environment and Natural Resource Management: Adaptation to Climate Change in Semi- Arid Environments Experience and Lessons from Mozambique. FAO, Rome, Italy. 71P.

Fischer D and Moriarty T (2011): Pesticide risk assessment for pollinators: Summary of a SETAC Pellston Workshop. Pensacola FL (USA): Society of Environmental Toxicology and Chemistry (SETAC) and Global Pesticide and Agrochemical Market to 2018

Fraizer M, State P and Caron D (2010): honey bee diseases and their maladies. The mid atlantic apiculture research and extension: Pp 61-75

Fries I and Compazine S (2001): Implications of horizontal and vertical pathogen transmission for honey bee epidemiology. Apidologie, 32: 199-214.

Genersch E (2010): Honey bee pathology: current threats to honey bees and beekeeping. Applid.Microbiology and Biotechnology, 87: 87-97.

Gezahegne T (2001): Beekeeping, Mega Printer Enterprise, and Addis Ababa, Ethiopia

Gizachew G, Sefinew A, Amssalu B and Malede B (2013): "Prevalence and Associated Risk Factors of Bee Lice in Holeta and its Surroundings, Ethiopia. Journal of Veterinary Science Technology: 4, $130 \mathrm{Pp}$

Haylegebriel T (2014): Honey Bee Diseases, Pest and Their Economic Importance in Ethiopia. International Journal of Innovation and Scientific Research, 10(2): Pp 527-535.

Hendrikx P, Debin M, and Chauzat P (2010): Bee mortality and bee surveillance in Europe. Pp 1-278.

Hood M (2004). The small hive beetle, Aethina tumida: a review, Bee World, 85(3): 51-59. Janine K, Martin D, Jose-Anne L, Coralie M and Noa Simon-D (2012). Assessment of pesticides risk for bees: methods for PNEC measurements. 11 International Symposium of the ICP-BR Bee Protection Group, Wageningen (The Netherlands), November 2-4, 2011

Johnson M, Ellis D, Mullin A and Frazier H (2010). Pesticides and honey bee toxicity - U.S.A., Apidologie, 41: 312-331. Journal of Food, Agriculture, Nutrition and development, 13(2): Pp 1-18.

Kajobe R, Agea G, Kugonza R, Alioni V, Otim S, Rureba T and Marris G (2009). National beekeeping calendar, honeybee pest, and disease control methods for improved production of honey \& other hive products in Uganda. A research report submitted to Natural Agricultural Research Organization (NARO), Entebbe Uganda. 
Kerealem E, Tilahun G and Preston R (2009). Constraints and prospects for apiculture research and development in Amhara region, Ethiopia. Livestock Resource and Rural Development, 21(10): Pp 1-14.

Keshlaf M (2017). The past and present status of beekeeping in Libya. Journal of Apicultural Research, pp. 190-195.

Maarec (2004). Beekeeping basics. delawar, Maryland ,new jersey, Pennsylvania, west Virginia, and USDA cooperating, Pp 46-47.

Marterre B (2008). Certified naturally grown apiary certification standards. Eastern apicultural society master beekeeper, North Carolina state beekeeper association master beekeeper, past president Forsyth county beekeepers association, past vice president and membership secretary.Pp.46-47.

Mustafa M and Williams R (2002): "New record of the small hive beetle in Egypt and notes on its distribution and control," Bee World. 83, Pp. 99-108.

OIE (2008): Nosemosis of honeybees. In: Manual for diagnostic tests and vaccines for terrestrial animals. Paris, Pp. 390392.

Razmarajii N and Karimi H (2010): A survey of Nosema of honeybees (Apis mellifera) in East Azarbaijan province of Iran. Journal of Animal and Veterinary advances, 9(5):879-882.

Shimanuki $\mathrm{H}$ and knox A (2000): diagnosis of honey bee disease. U.S. department of agriculture, agriculture hand book. Pp. 16-35.

SNV (2009): Integrated Value Chain Analyses for Honey and Beeswax Production in Ethiopia and Prospects for Exports. The Netherlands Development Organization.

Sokh R, Molaska M and Siuda M (2007): The influence of the invasion of Nosema Apis on the number of pollen seeds in bee's intestine. Polish Journal of Natural Science, 22:150-156.

Strauss U, Human H, Gauthier L, Crewe M, Dietemann V and Pirk W (2013): Seasonal prevalence of pathogens and parasites in the savannah honeybee (Apis mellifera scutellata). Journal of invertebrate Pathology, 114(1): Pp 45-52.

Tessega B (2009): Honeybee Production and Marketing Systems, Constraints and Opportunities in Burie District of Amhara Region, Ethiopia. Pp116.

Tumlinson Y, Evans D and Suresh R (2010): A scientific note on Varroa destructor found in East Africa; threat or opportunity? Apidologie, 41: Pp 463-465.

Workneh A and Puskur R (2011): Beekeeping Sub Sector Challenges and Constraints in Atsbi Wemberta District of Eastern Zone, Tigray Region, Ethiopia. Journal of Agriculture Extension and Rural development, 3(1): Pp 8-12. 